\title{
Development and Sensory Evaluation of Aloevera and Coconut Water based Whey Beverages Prepared from Camel and Goat Milk
}

Nitesh Chand Sharma1, Basant Bais ${ }^{1}$, Jayesh Vyas², Ajay Sharma ${ }^{1}$

10.18805/ajdfr.DR-1742

\begin{abstract}
Background: Aloevera juice, coconut water, honey and whey may be used to form a medicinal, prophylactic and nutritionally rich product, which might boost its demand in the food and beverage business.

Methods: The purpose of the research was to formulating the different types of whey beverages and estimate the sensory quality of whey beverages which prepared from camel and goat milk $(70 \%, 30 \%)$. The formation of whey beverages blended in various combinations of whey, alovera juice $(5 \%, 10 \%$ and $15 \%)$, coconut water $(5 \%, 10 \%$ and $15 \%)$, honey $(5 \%)$ and black salt $(1 \%)$.

Result: On the basis of sensory evaluation such as appearance/colour, flavour, taste and overall acceptability the preparation of alovera based whey beverages with a composition of $79 \%$ whey and $15 \%$ alovera juice $\left(T_{1} A_{3}\right)$ had obtained maximum overall acceptability $(7.54 \pm 0.050)$, whereas for coconut water-based whey beverage the composition of $79 \%$ whey and $15 \%$ coconut water $\left(T_{2} C_{3}\right)$ had obtained maximum overall acceptability $(7.29 \pm 0.032)$. In comparison to control whey beverage, fortified whey aloevera beverage and whey coconut water beverage was found to be more acceptable because it had a good flavour and taste, as well as overall acceptability.

Key words: Aloevera juice, Coconut water, Sensory evaluation, Whey beverages.
\end{abstract}

\section{INTRODUCTION}

Whey is the watery liquid left after milk has been curdled and strained. It contains approximately half of the total milk solids and is a source of essential nutrients such as whey proteins, lactose, milk salts and most of the vitamins that are water soluble (Naik et al., 2009). Whey has preventive and healing components and is particularly used to treat a wide range of disorders, such as arthritis, anaemia and liver complaints (Cruz et al., 2009).

The camel (Camelus dromedarius) has significant socioeconomic importance in arid and semiarid regions (Rajasthan) of the world and its milk constitutes an important component of human diets in these regions (Rajasthan). More recently, studies have reported that camel milk is unique in terms of antioxidative factors, antibacterial, antiviral, antifungal, antihepatitis, paratuberculosis, hypoglycaemic function, anticancer, aging prevention and autoimmune disease remedy (Sharma and Singh, 2014).

Goat (Capra hircus) milk is used to treat various conditions including stomach disorders, vomiting, colic, diarrhoea, constipation and breathing problems (Getaneh et al., 2016). Goat milk is vital for the prevention and immune stimulation of cardiovascular diseases, cancers, allergies and microorganisms. For children, an elderly and convalescent person, goat milk is recommended (Zenebe et al., 2014).

The aloevera (Aloe barbadensis) gel is an important for type-2 diabetes as an antihyperglycemic agent. It decreases the amount of blood glucose without disturbing the usual level of blood lipids and liver/kidney function (Huseini et al., 2012). Whereas, it contains a variety of antioxidants, such as alpha-tocopherol, carotenoids,
${ }^{1}$ Department of Livestock Products Technology, College of Veterinary and Animal Science, Rajasthan University of Veterinary and Animal Sciences, Bikaner-334 001, Rajasthan, India.

${ }^{2}$ Department of Animal Genetics and Breeding, College of Veterinary and Animal Science, Rajasthan University of Veterinary and Animal Sciences, Bikaner-334 001, Rajasthan, India.

Corresponding Author: Nitesh Chand Sharma, Department of Livestock Products Technology, College of Veterinary and Animal Science, Rajasthan University of Veterinary and Animal Sciences, Bikaner-334 001, Rajasthan, India.

Email: sharma.nitesh1220@gmail.com

How to cite this article: Sharma, N.C., Bais, B., Vyas, J. and Sharma, A. (2022). Development and Sensory Evaluation of Aloevera and Coconut Water based Whey Beverages Prepared from Camel and Goat Milk. Asian Journal of Dairy and Food Research. DOI: 10.18805/ajdfr.DR-1742.

Submitted: 02-06-2021 Accepted: 08-12-2021 Online: 22-02-2022 ascorbic acid, flavonoids, vitamin C and E, tannins (Radha and Laxmipriya, 2015).

Coconut (Cocos nucifera) water can help for regulating the level of blood sugar, prevent diabetes, improve cardiovascular health and lower the risk of serious cardiovascular disease by lowering the cholesterol/ triglyceride levels. It can be beneficial for blood pressure control and helps to lower the risk of heart diseases and help in balancing the electrolytes of the body (Bhagya et al., 2010).

Honey has many antioxidants that are protective against the development of cancer. It is anti-bacterial, anti-viral and anti-fungal and it is suitable for wound healing with all of 
these properties. Asthmatic people will benefit from taking honey every day as well (Kumar et al., 2010).

Looking at the health benefits of aloevera juice, coconut water and whey, the aim of study was to produce whey beverages that are nutritious as well as palatable with different proportions of aloevera juice and coconut were developed.

\section{MATERIALS AND METHODS}

Whey obtained during process of paneer preparation by using $70 \%$ of camel milk and $30 \%$ of goat milk was used to prepare control whey beverage $\left(\mathrm{T}_{0}\right)$ and treatment whey beverages. The following treatment combinations were formulated (Table 1 and 2):

$\mathrm{T}_{0}$ (Control)- Whey beverage contains $94 \%$ plain whey, $5 \%$ honey and $1 \%$ black salt.

$\mathrm{T}_{1} \mathrm{~A}_{1}$ - Aloevera based whey beverage contains $89 \%$ whey, $5 \%$ aloevera juice, $5 \%$ honey and $1 \%$ black salt.

$\mathrm{T}_{1} \mathrm{~A}_{2}$ - Aloevera based whey beverage contains $84 \%$ whey, $10 \%$ aloevera juice, $5 \%$ honey and $1 \%$ black salt.

$\mathrm{T}_{1} \mathrm{~A}_{3}$ - Aloevera based whey beverage contains $79 \%$ whey, $15 \%$ aloevera juice, $5 \%$ honey and $1 \%$ black salt.

$\mathrm{T}_{2} \mathrm{C}_{1}$ - Coconut water based whey beverage contains $89 \%$ whey, $5 \%$ coconut water, $5 \%$ honey and $1 \%$ black salt.

$\mathrm{T}_{2} \mathrm{C}_{2}$-Coconut water based whey beverage contains $84 \%$ whey, $10 \%$ coconut water, $5 \%$ honey and $1 \%$ black salt.

$\mathrm{T}_{2} \mathrm{C}_{3}$ - Coconut water based whey beverage contains $79 \%$ whey, $15 \%$ coconut water, $5 \%$ honey and $1 \%$ black salt.

A jury of five judges evaluated prepared drinks using an 8-point hedonic scale to determine sensory characteristics such as appearance/color, flavour, taste and overall acceptability. The sensory assessment involved eight semi-trained panelists (Randomly selected members from college these are like Assistant Professors, Professors, Students and other persons). Under fluorescent light, the control whey beverage, as well as all of the aloevera-based whey beverages and coconut water-based whey beverages, is delivered in clear plastic bottles. All samples were labeled and the order in which they were shown to each panelist was randomized and after properly examined panelists give their result of given parameter of 8-point hedonic scale.

\section{RESULTS AND DISCUSSION Sensory evaluation}

On the basis of this above sensory assessment we prepared the final table of sensory evaluation of whey beverages which has been presented in Table 3 and depicted in Fig 1. The average point for appearance/color, taste and flavor for different whey beverages varies from 6.10 to 7.70 . The average point for appearance/ color of control or plain whey beverage $\left(T_{0}\right)$ was found to be $6.14 \pm 0.032$ and for aloevera based whey beverage i.e. for $T_{1} A_{1}, T_{1} A_{2}$ and $T_{1} A_{3}$, it was found to be $6.63 \pm 0.028,7.02 \pm 0.017$ and $7.56 \pm 0.052$, respectively and for coconut water based whey beverage i.e. $\mathrm{T}_{2} \mathrm{C}_{1}, \mathrm{~T}_{2} \mathrm{C}_{2}$ and $\mathrm{T}_{2} \mathrm{C}_{3}$ the average point for appearance/ color were observed to be $6.43 \pm 0.027,6.74 \pm 0.029$ and $7.44 \pm 0.038$, respectively.

It may be observed that $T_{1} A_{3}$ scored maximum point (7.56 \pm 0.052$)$ for appearance/color by the panelists whereas control or plain whey beverage obtained minimum point $(6.14 \pm 0.032)$ for appearance/color. So, it may be concluded that the inclusion of aloevera and coconut water improve appearance/color of treatment whey beverages as compared to control whey beverage.

Table 1: Formulation for preparation of $100 \mathrm{ml}$ of aloevera based whey beverages (ABWB).

\begin{tabular}{lcccc}
\hline Treatment & $\begin{array}{c}\text { Whey } \\
(\%)\end{array}$ & $\begin{array}{c}\text { Aloevera } \\
\text { juice }(\%)\end{array}$ & $\begin{array}{c}\text { Honey } \\
(\%)\end{array}$ & $\begin{array}{r}\text { Black } \\
\text { salt }(\%)\end{array}$ \\
\hline $\mathrm{T}_{0}($ Control $)$ & 94 & 0 & 5 & 1 \\
$\mathrm{~T}_{1} \mathrm{~A}_{1}$ & 89 & 5 & 5 & 1 \\
$\mathrm{~T}_{2} \mathrm{~A}_{2}$ & 84 & 10 & 5 & 1 \\
$\mathrm{~T}_{1} \mathrm{~A}_{3}$ & 79 & 15 & 5 & 1 \\
\hline
\end{tabular}

Table 2: Formulation for preparation of $100 \mathrm{ml}$ of coconut water based whey beverages (CBWB).

\begin{tabular}{lcccc}
\hline Treatment & $\begin{array}{c}\text { Whey } \\
(\%)\end{array}$ & $\begin{array}{c}\text { Coconut } \\
\text { water }(\%)\end{array}$ & $\begin{array}{c}\text { Honey } \\
(\%)\end{array}$ & $\begin{array}{r}\text { Black } \\
\text { salt }(\%)\end{array}$ \\
\hline $\mathrm{T}_{0}$ (Control) & 94 & 0 & 5 & 1 \\
$\mathrm{~T}_{2} \mathrm{C}_{1}$ & 89 & 5 & 5 & 1 \\
$\mathrm{~T}_{2} \mathrm{C}_{2}$ & 84 & 10 & 5 & 1 \\
$\mathrm{~T}_{2} \mathrm{C}_{3}$ & 79 & 15 & 5 & 1 \\
\hline
\end{tabular}

Table 3: Sensory evaluation of prepared whey beverages.

\begin{tabular}{lcccc}
\hline Treatment & Appearance/color & Flavor & Taste & Overall acceptability \\
\hline $\mathrm{T}_{0}$ & $6.14^{\mathrm{a}} \pm 0.032$ & $6.23^{\mathrm{b}} \pm 0.027$ & $6.10^{\mathrm{a}} \pm 0.052$ & $6.61^{\mathrm{a}} \pm 0.011$ \\
$\mathrm{~T}_{1} \mathrm{~A}_{1}$ & $6.63^{\mathrm{a}} \pm 0.028$ & $6.73^{\mathrm{c}} \pm 0.048$ & $6.53^{\mathrm{a}} \pm 0.032$ & $6.63^{\mathrm{c}} \pm 0.028$ \\
$\mathrm{~T}_{1} \mathrm{~A}_{2}$ & $7.02^{\mathrm{f}} \pm 0.017$ & $7.13^{\mathrm{d}} \pm 0.063$ & $6.95^{\mathrm{d}} \pm 0.038$ & $7.03^{\mathrm{d}} \pm 0.022$ \\
$\mathrm{~T}_{1} \mathrm{~A}_{3}$ & $7.56^{\mathrm{e}} \pm 0.052$ & $7.70^{\mathrm{f}} \pm 0.049$ & $7.38^{\mathrm{f}} \pm 0.027$ & $7.54^{\mathrm{f}} \pm 0.050$ \\
$\mathrm{~T}_{2} \mathrm{C}_{1}$ & $6.43^{\mathrm{b}} \pm 0.027$ & $6.12^{\mathrm{a}} \pm 0.026$ & $6.23^{\mathrm{b}} \pm 0.023$ & $6.26^{\mathrm{b}} \pm 0.019$ \\
$\mathrm{~T}_{2} \mathrm{C}_{2}$ & $6.74^{\mathrm{d}} \pm 0.029$ & $6.71^{\mathrm{e}} \pm 0.031$ & $6.63^{\mathrm{c}} \pm 0.044$ & $6.69^{\mathrm{c}} \pm 0.034$ \\
$\mathrm{~T}_{2} \mathrm{C}_{3}$ & $7.44^{ \pm} \pm 0.038$ & $7.32^{\mathrm{e}} \pm 0.026$ & $7.11^{ \pm} \pm 0.043$ & $7.29^{\mathrm{e}} \pm 0.032$ \\
\hline
\end{tabular}

Means bearing different superscripts within column (small letter) differ significantly. ${ }^{* *}=$ Highly Significant $(P<0.01) . T_{0}$ (Control or plain whey beverage), $T_{1} A_{1}$ (Aloevera based whey beverage 5\%), $T_{1} A_{2}$ (Aloevera based whey beverage 10\%), $T_{1} A_{3}$ (Aloevera based whey beverage $15 \%$ ), $T_{2} C_{1}$ (Coconut water-based whey beverage $5 \%$ ), $T_{2} C_{2}$ (Coconut water-based whey beverage $10 \%$ ), $T_{2} C_{3}($ Coconut water-based whey beverage $15 \%$ ). 
The average point for flavor of $T_{0}$ was observed to be 6.23 \pm 0.027 , whereas for $T_{1} A_{1}, T_{1} A_{2}$ and $T_{1} A_{3}$ were observed to be $6.73 \pm 0.048,7.13 \pm 0.063$ and $7.70 \pm 0.049$, respectively and for coconut water-based whey beverages i.e., $\mathrm{T}_{2} \mathrm{C}_{1}, \mathrm{~T}_{2} \mathrm{C}_{2}$ and $\mathrm{T}_{2} \mathrm{C}_{3}$ were observed $6.12 \pm 0.026,6.71 \pm 0.031$ and $7.32 \pm 0.026$, respectively. Thus, from the results obtained for flavor of different treatment beverages, it may be observed that $T_{1} A_{3}$ obtained maximum $(7.70 \pm 0.049)$ for flavor by the panelists whereas control or plain whey beverage scored minimum point $(6.23 \pm 0.027)$. Thus, it may be concluded that inclusion of aloevera and coconut water improve flavor of treatment whey beverages as compared to control whey beverage.

The average point for taste of $\mathrm{T}_{0}$ (control) or plain whey beverage without addition of aloevera juice or coconut water was observed to be $6.10 \pm 0.052$ whereas for $T_{1} A_{1}, T_{1} A_{2}$ and $T_{1} A_{3}$ were found $6.53 \pm 0.032,6.95 \pm 0.038$ and $7.38 \pm 0.027$, respectively and for $T_{2} C_{1}, T_{2} C_{2}$ and $T_{2} C_{3}$ were observed $6.23 \pm 0.023,6.63 \pm 0.044$ and $7.11 \pm 0.043$, respectively. From the results obtained for taste of different treatment beverages it may be observed that $T_{1} A_{3}$ scored maximum point $(7.38 \pm 0.027)$ for taste by the panelists whereas control or plain whey beverage obtained minimum point $(6.10 \pm 0.052)$. Thus, it may be concluded that inclusion of aloevera and coconut water improve taste of treatment whey beverages as compared to control whey beverage.

On the basis of data presented in Table 3 whey beverages with a composition of $79 \%$ whey and $15 \%$ aloevera juice $\left(T_{1} A_{3}\right)$ had obtained maximum overall acceptability $(7.54 \pm 0.050)$ whereas for coconut water based whey beverage the composition of $79 \%$ whey and $15 \%$ coconut water $\left(\mathrm{T}_{2} \mathrm{C}_{3}\right)$ had obtained maximum overall acceptability $(7.29 \pm 0.032)$.

All the parameters of sensory evaluation are highly significant from each other $(P \leq 0.01)$ for the all treatments of whey beverages. The variation in the sensory scores awarded for various fruit juice blends whey beverages on Overall acceptability can be due to customers' personal preferences for certain colours, flavours and tastes. The results of present investigation related to appearance/ color, taste, flavor and overall acceptability are agreement with the results of (Gorachiya, 2018) who also reported that control or plain whey beverage obtained minimum score for appearance/color, taste, flavor and overall acceptability than the treatment whey beverages. Similar study of sensory analysis was also conducted by Bhavsager et al. (2010), Kumar (2015), Abdulalim et al. (2018), Rohit et al. (2020) and Sharma et al. (2020).

\section{Antioxidant properties}

The determination of the ABTS activity ( $\%$ inhibition) was done to test the antioxidant properties of aloevera based whey beverages and coconut water based whey beverage as compared to control whey beverage. The analysis of ABTS activity (\% inhibition) of whey based beverage was done under refrigerated storage condition $(0,3,6,9$ and 12

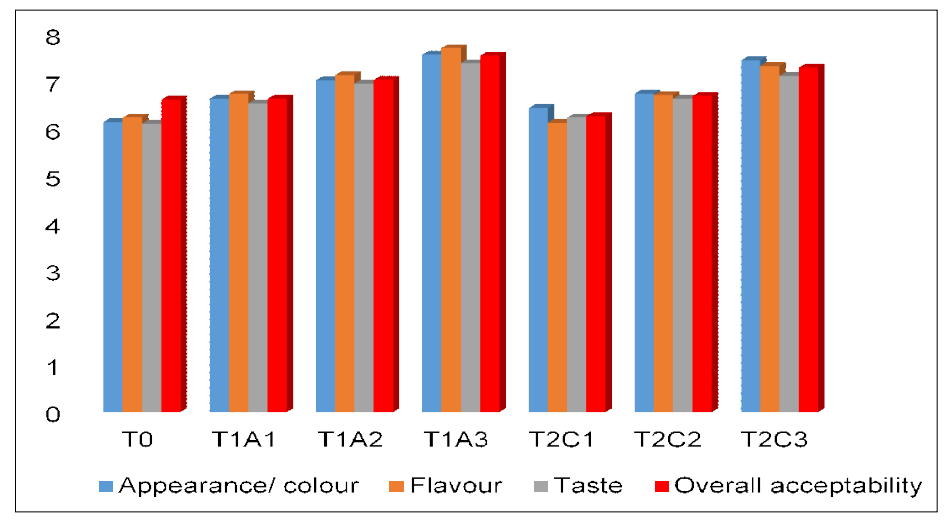

Fig 1: Sensory evaluation of whey beverages. $T_{0}-$ Control, $T_{1} A_{3}-$ Aloevera based whey beverage, $T_{2} C_{3}$ - Coconut water based beverage.

Table 4: ABTS activity (\% inhibition) (mean \pm SE) of prepared whey beverages.

\begin{tabular}{lcccc}
\hline Day & $\mathrm{T}$ & $\mathrm{T}$ & $\mathrm{T}$ & Overall \\
\hline Day 0 & $12.06^{\mathrm{eA}} \pm 0.017$ & $31.56^{\mathrm{eC}} \pm 0.012$ & $28.54^{\mathrm{e}} \pm 0.024$ & $24.06^{\mathrm{e}} \pm 3.030$ \\
Day 3 & $11.93^{\mathrm{dA}} \pm 0.017$ & $28.35^{\mathrm{dC}} \pm 0.020$ & $25.33^{\mathrm{dB}} \pm 0.014$ & $21.88^{\mathrm{d}} \pm 2.522$ \\
Day 6 & $9.84^{\mathrm{CA}} \pm 0.024$ & $24.26^{\mathrm{CC}} \pm 0.012$ & $22.16^{\mathrm{cB}} \pm 0.015$ & $18.76^{\mathrm{c}} \pm 2.249$ \\
Day 9 & $8.34^{\mathrm{bA}} \pm 0.024$ & $22.46^{\mathrm{bC}} \pm 0.088$ & $19.34^{\mathrm{bB}} \pm 0.014$ & $16.72^{\mathrm{b}} \pm 2.141$ \\
Day 12 & $6.83^{\mathrm{aA}} \pm 0.017$ & $19.54^{\mathrm{aC}} \pm 0.018$ & $15.94^{\mathrm{aB}} \pm 0.014$ & $14.11^{\mathrm{a}} \pm 1.890$ \\
Overall & $9.80^{\mathrm{A}} \pm 3.030$ & $25.23^{\mathrm{C}} \pm 2.522$ & $22.26^{\mathrm{B}} \pm 2.249$ & \\
\hline
\end{tabular}

Means bearing different superscript in a column (capital letter) and in a row (small letter) differ significantly. ${ }^{* *}=$ Highly significant $(P<0.01)$. $T_{0}$ - Control whey beverage, $T_{1}$ - Aloevera based whey beverage (ABWB) and $T_{2}$ - Coconut water based whey beverage $(C B W B)$. 
days). The data of ABTS activity (\% inhibition) has been shown in Table 4 and depicted in Fig 2. The present investigation of ABTS activity are in accordance of significant decrease with respect to the storage period were reported by Baba et al. (2016), Sady et al. (2013), Tak, (2017), Singh, (2017), Gorachiya (2018), Prajapat (2019), Singh (2020), León-López et al. (2020).

\section{Proximate analysis}

The data of proximate analysis of whey beverages which included moisture, dry matter, crude protein, ether extract and total ash has been presented in Table 5 and depicted in Fig 3. Present investigations are variable with the findings of (Rohit et al.,2019) reported the moisture content of kiwi fruit whey drinks was $90.31,86.35,84.49$ and $83.14 \%, 0.47$,
$0.51,0.56$ and $0.58 \%$ protein, $0.38,0.47,0.52$ and $0.57 \%$ ash for $\mathrm{T}_{1}, \mathrm{~T}_{2}, \mathrm{~T}_{3}$ and $\mathrm{T}_{4}$ treatment, respectively. Whereas the treatments $T_{0}$ (control), $T_{1}(5 \%), T_{2}(10 \%)$ and $T_{3}(15 \%)$ of the pineapple flavoured chhana whey beverage containing protein $057,0.66,0.73$ and $12.67 \%$, ash $0.44,0.60,0.76$ and 0.78 per cent and moisture $86.71,86.20,85.62$ and 85.50 per cent, respectively, these findings were reported by Bhavsager et al. (2010).

\section{Cost of whey beverages}

The cost of production per liter of plain whey beverage (control or $\mathrm{T}_{0}$ ) was worked out as Rs. 25 whereas aloevera based whey beverage $\left(T_{1} A_{3}\right)$ was worked out as Rs. 36.2 and coconut water based whey beverage $\left(\mathrm{T}_{2} \mathrm{C}_{3}\right)$ was worked out as Rs. 54.2.

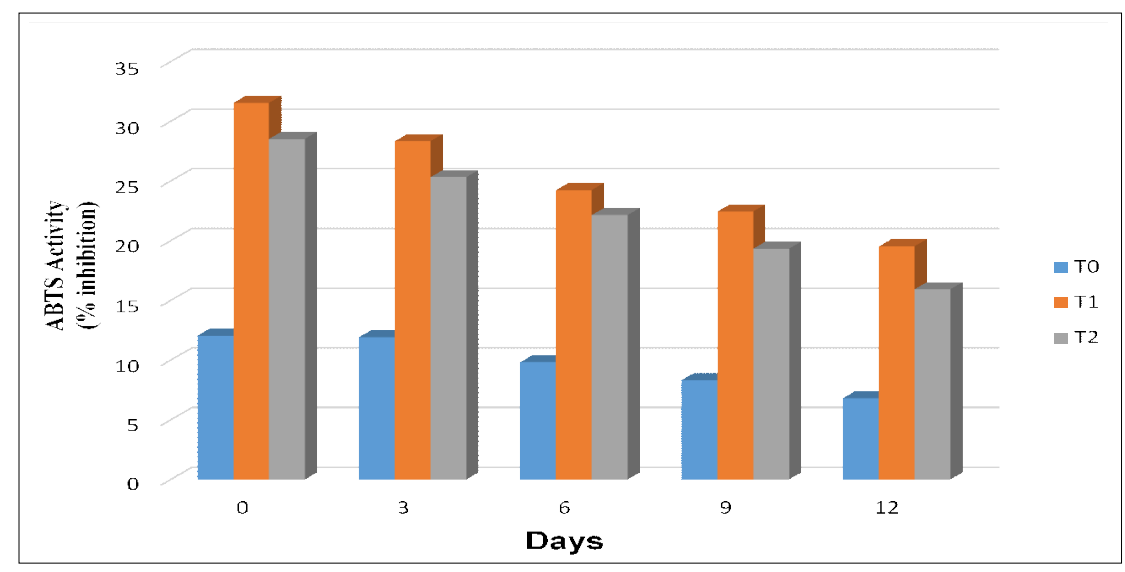

Fig 2: ABTS (\% inhibition) of prepared whey beverages. $T_{0}$ - Control, $T_{1} A_{3}$ - Aloevera based whey beverage, $T_{2} C_{3}-$ Coconut water based beverage.

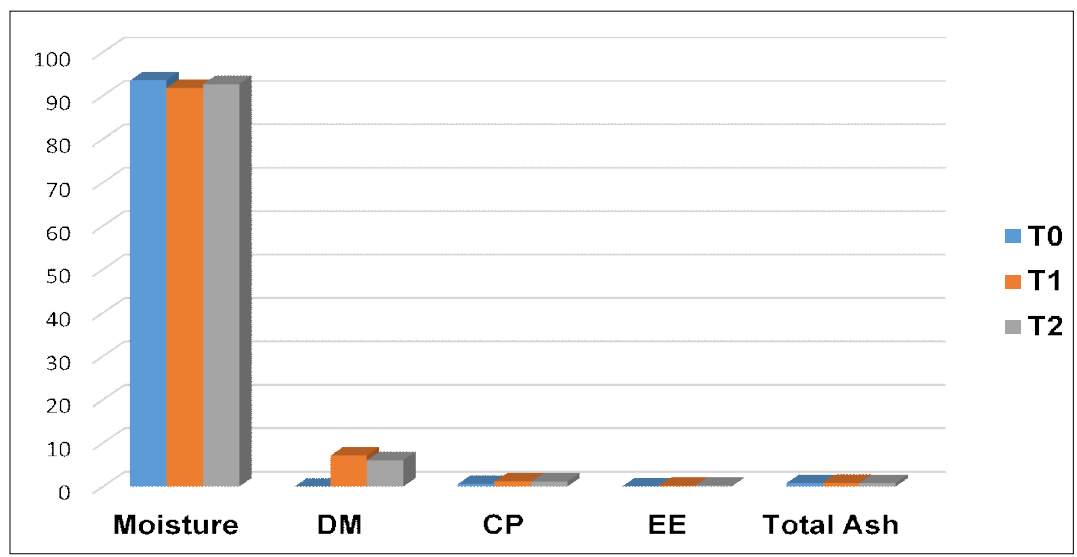

Fig 3: Proximate analysis of prepared whey beverages. $T_{0}$ - Control, $T_{1} A_{3}$ - Aloevera based whey beverage, $T_{2} C_{3}-$ Coconut water based beverage.

Table 5: Proximate analysis (mean \pm SE) of prepared whey beverages.

\begin{tabular}{lccccc}
\hline Treatment & Moisture & Dry matter & Crude matter & Ether extract & Total ash \\
\hline $\mathrm{T}_{0}$ & $93.58^{\mathrm{c}} \pm 0.052$ & $5.63^{\mathrm{a}} \pm 0.024$ & $0.71^{\mathrm{a}} \pm 0.017$ & $0.15^{\mathrm{a}} \pm 0.035$ & $0.84^{\mathrm{a}} \pm 0.031$ \\
$\mathrm{~T}_{1} \mathrm{~A}_{3}$ & $91.82^{\mathrm{a}} \pm 0.014$ & $7.25^{\mathrm{b}} \pm 0.031$ & $1.23^{\mathrm{a}} \pm 0.024$ & $0.22^{\mathrm{b}} \pm 0.023$ & $0.94^{\mathrm{b}} \pm 0.017$ \\
$\mathrm{~T}_{2} \mathrm{C}_{3}$ & $92.74^{\mathrm{b}} \pm 0.029$ & $6.11^{\mathrm{a}} \pm 0.046$ & $1.20^{\mathrm{b}} \pm 0.028$ & $0.27^{\mathrm{c}} \pm 0.026$ & $0.86^{\mathrm{b}} \pm 0.025$ \\
\hline
\end{tabular}

Means bearing different superscripts within column (small letter) differ significantly. ${ }^{* *}=$ Highly significant $(P<0.01) . T_{0}-$ Control whey beverage, $T_{1} A_{3}$ - Aloevera based whey beverage (ABWB), $T_{2} C_{3}$ - Coconut water-based whey beverage (CBWB). 


\section{CONCLUSION}

The main contribution of this study was to provide new knowledge about whey and whey-based beverages with its health benefits and nutritious properties. Whey beverages prepared from camel and goat milk $(70 \%$ and $30 \%)$ with addition of different levels of aloevera juice and coconut water added with constant level of honey and black salt was found to be highly acceptable. In comparison to control whey beverage, fortified whey-aloevera beverage and whey coconut water beverage was found to be more acceptable as it gave good flavour and taste and overall acceptability. It is therefore concluded, among all the beverages, $T_{1} A_{3}$ obtained maximum acceptability, antioxidant property \{as per mean ABTS activity $25.23 \pm 2.522$ (at 0 to 12 days) $\}$ and lower cost (Rs. 36.2) and best for production. Since the beverage was made from discarded whey water, it contributes to a lower cost and has thus proved to be commercially viable.

Conflict of interest: None.

\section{REFERENCES}

Abdulalim, T. S., Zayan A. F., Campelo P. H. and Bakry A. M. (2018). Development of new functional fermented product: mulberry-whey beverage. Journal of Nutritional Food Technology. 1: 64-69.

Baba, W. N., Din, S., Punoo, H. A., Wani, T. A., Ahmad, M., and Masoodi, F. A. (2016). Comparison of cheese and paneer whey for production of a functional pineapple beverage: Nutraceutical properties and Shelf life. Journal of Food Science and Technology. 53(6): 2558-2568.

Bhagya D., Prema L. and Rajamohan, T. (2010). Tender coconut water maintains the level of electrolytes and renin in fructose-fedhypertensive rats. International Journal of Biological and Medical Research. 1: 44-48.

Bhavsagar M. S., Awaz H. B. and Patange U. L. (2010). Manufacture of pineapple flavoured beverage from chhana whey. Journal of Dairying, Foods and Home Science. 29:110-113.

Cruz, A. G., Sant'Ana, A. D. S., Macchione, M. M., Teixeira, Â. M. and Schmidt, F. L. (2009). Milk drink using whey butter cheese (queijomanteiga) and acerola juice as a potential source of vitamin C. Food and Bioprocess Technology. 2: 368-373.

Getaneh, G., Mebrat, A., Wubie, A., and Kendie, H. (2016). Review on goat milk composition and its nutritive value. Journal of Nutrition and Health Sciences. 3(4): 401-410.

Gorachiya P. (2018). Studies on the Development and Evaluation of Naturally Flavoured Whey Beverages from Camel and Buffalo Milk. M.V.Sc. Thesis presented to Rajasthan University of Veterinary and Animal Sciences, Bikaner.

Huseini, H. F., Kianbakht, S., Hajiaghaee, R. and Dabaghian, F.H. (2012). Antihyperglycemic and anti-hypercholesterolemic effects of Aloevera leaf gel in hyperlipidemic type 2 diabetic patients: A randomized double-blind placebocontrolled clinical trial. Planta medica. 78 : 311-316.
Kumar, K.S., Bhowmik, D., Biswajit, C. and Chandira, M. R. (2010). Medicinal uses and health benefits of honey: An Overview. Journal of Chemical and Pharmaceutical Research. 2: 385-395.

Kumar, R.S. (2015). Development, quality evaluation and shelf life studies of probiotic beverages using whey and aloevera juice. Journal of Food Processing and Technology. 6(9).

León-López, A., Pérez-Marroquín, X. A., Campos-Lozada, G., Campos- Montiel, R. G. and Aguirre-Álvarez, G. (2020). Characterization of whey-based fermented beverages supplemented with hydrolyzed collagen: antioxidant activity and bioavailability. Foods. 9(8): 1106.

Naik, Y. K., Khare, A., Choudhary, P. L., Goel, B. K. and Shrivastava, A. (2009). Studies on physico-chemical and sensory characteristics of whey based watermelon beverage. Asian Journal of Research in Chemistry. 2: 57-59.

Prajapat, A. (2019) Development and quality evaluation of spices incorporated camel and goat milk paneer M.V.Sc. Thesis submitted to Rajasthan University of Veterinary and Animal Sciences, Bikaner.

Radha, M. H. and Laxmipriya, N.P. (2015). Evaluation of biological properties and clinical effectiveness of Aloevera: A systematic review. Journal of traditional and complementary medicine. 5: 21-26.

Rohit, I., Chavan, K., More, R. and Dnyaneshwar, W. (2020). Studies on effect of using kiwi (Actinidiadeliciosa) fruit extract on sensory properties of fruit based Chhana whey beverage. Journal of Pharmacognosy and Phytochemistry. 9: 522-526.

Sady, M., Jaworska, G., Grega, T., Bernas, E. and Domagala, J. (2013). Application of acid whey in orange drink production. Food Technology and Biotechnology. 51(2): 266.

Sharma, C. and Singh, C. (2014). Therapeutic value of camel milkA Review. Advanced Journal of Pharmacie and Life Science Research. 2: 7-13.

Sharma, N., Chavan, K. D. and Jaybhay, V. B. (2020). Effect of ginger (Zingiber officinalis L.) on quality and shelf life of Chhana whey beverage. Journal of Information and Communication Technology Research. 8: 931-936.

Singh, J. (2020). Studies on the development and quality evaluation of camel and buffalo milk based khoa burfi blended with watermelon seeds. M.V.Sc. Thesis submitted to Rajasthan University of Veterinary and Animal Sciences, Bikaner.

Singh S. (2017). Studies on the Fermentative Potential of Camel and Buffalo Milk by using Lactococcus lactis ssp. cremoris and Lactococcus lactis ssp. Lactis. M.V.Sc. Thesis presented to Rajasthan University of Veterinary and Animal Sciences, Bikaner.

Tak, L. (2017). Studies on the fermentative potential of camel and buffalo milk by using Lactobacillus fermentum and Lactobacillus helveticus. M.V.Sc. Thesis presented to Rajasthan University of Veterinary and Animal Sciences, Bikaner.

Zenebe, T., Ahmed, N., Kabeta, T. and Kebede, G. (2014). Review on medicinal and nutritional values of goat milk. Academic Journal of Nutrition. 3: 30-39. 